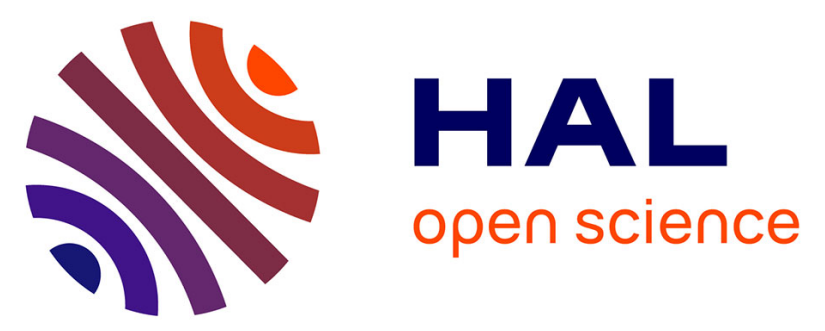

\title{
Promoting next generation vehicles in Japan: the smart communities and their experimentations
}

\author{
Bruno Faivre d'Arcier, Yveline Lecler
}

\section{To cite this version:}

Bruno Faivre d'Arcier, Yveline Lecler. Promoting next generation vehicles in Japan: the smart communities and their experimentations. International Journal of Automotive Technology and Management, 2014, Sustainable Urban Mobility in Comparison, 14 (3/4), pp.324-346. 10.1504/IJATM.2014.065296 . halshs-01092314

\section{HAL Id: halshs-01092314 \\ https://shs.hal.science/halshs-01092314}

Submitted on 19 May 2017

HAL is a multi-disciplinary open access archive for the deposit and dissemination of scientific research documents, whether they are published or not. The documents may come from teaching and research institutions in France or abroad, or from public or private research centers.
L'archive ouverte pluridisciplinaire HAL, est destinée au dépôt et à la diffusion de documents scientifiques de niveau recherche, publiés ou non, émanant des établissements d'enseignement et de recherche français ou étrangers, des laboratoires publics ou privés.

\section{(ㅇ)(1) $\$$}

Distributed under a Creative Commons Attribution - NonCommercial - NoDerivatives $\mid 4.0$ 


\title{
Promoting next generation vehicles in Japan: the smart communities and their experimentations
}

\section{Bruno Faivre d'Arcier}

Transport Economics Laboratory - LET, University of Lyon: Lyon 2,

(CNRS UMR 5593), ISH - 14 avenue Berthelot, 69007 Lyon, France

E-mail: bfdarcier@let.ish-lyon.cnrs.fr

\section{Yveline Lecler*}

Institute of East Asian Studies - IAO, University of Lyon: Sciences Po Lyon, (CNRS UMR 5062),

Ecole Normale Supérieure de Lyon, 15 Parvis René Descartes BP 7000, 69342 Lyon Cedex, France E-mail: yveline.lecler@ens-lyon.fr *Corresponding author

\begin{abstract}
The development of smart grids opens up interesting perspectives in order to make better use of local renewable energy production, reduce $\mathrm{CO}_{2}$ emissions, giving therefore more emphasis on electrical vehicles. After having briefly described mobility characteristics in Japan and introduced the Japanese context that led to the wide range of new policies implementation aiming at building a low carbon society and at promoting next generation vehicles, the paper concentrates on an extensive programme launched by the Japanese Ministry of Economy, Trade and Industry (METI) in 2010 to promote the development of 'smart communities'. Taking the case of Toyota city Smart Melit experimentation as a concrete illustration, it discusses the main actions undertaken before examining some preliminary results in terms of users' behaviour and the consequences that present and expected future changes might have on the mobility ecosystem and on car maker business model.
\end{abstract}

Keywords: Japan; e-mobility ecosystem; next generation vehicles; smart communities; Toyota Smart Melit project; automotive business model.

Reference to this paper should be made as follows: Faivre d'Arcier, B. and Lecler, Y. (xxxx) 'Promoting next generation vehicles in Japan: the smart communities and their experimentations', Int. J. Automotive Technology and Management, Vol. X, No. Y, pp.000-000.

Biographical notes: Bruno Faivre d'Arcier is Professor at the University of Lyon 2, Director of the Transport Department at the Faculty of Economics and Management, and Senior Research Fellow at the Transport Economics Laboratory (CNRS). He holds a diploma in Engineering and PhD in Transport Economics from the University of Lyon 2. He specialised in local passenger transport policies and planning, his research activity now concerns the development of sustainable urban mobility plans in cities, with a particular 
focus on urban public transport funding and pricing, transport policy assessment, mobility management and travel behaviour analysis. He was recently awarded at the 13th World Conference on Transport Research (WCTR, Rio, July 2013) with Pr. Alain Bonnafous for their paper untitled 'The conditions of efficiency of a PPP for public finances'.

Yveline Lecler is Professor at the University of Lyon, Sciences-Po and Senior Research Fellow at the Institute of East Asian Studies (ENSL, CNRS). She holds a PhD in Social Sciences from EHESS Paris. She specialised in Japanese and Asian political economics, she used to study SMEs and subcontracting mainly in car and electronic industries. Her recent researches focus on innovation policies, presently in relation with energy management, low carbon cities and new mobility. She published a lot of papers in journals and wrote or edited several books, among which The Dynamics of Regional Innovation, the Policy Challenges in Europe and Japan, co-edited with Yoshimoto Tetsuo and Fujimoto Takahiro (2012, World Scientific). She has been a Visiting Professor in several Japanese universities.

This paper is a revised and expanded version of a paper entitled 'New e-automotive based services: the Japanese smart communities and their experimentations' presented at 21st GERPISA International Meeting, Paris, 12-14 June 2013.

\section{Introduction}

In connection with the climatic imperatives, the objective of sustainable development leads to the search of less energy consumption practices, at least in the field of non-renewable resources. In the urban world, the energy consumption is still particularly important in the two areas of housing and transports. There have been attempts to create more energy efficient cities for a long time, as evidenced by many achievements of sustainable districts, or eco-districts (mainly residential areas) in various European countries. However, these new districts have often focused on recycling and on reducing energy consumption by developing new standards in the construction of buildings. In Japan, the government has also initiated many programmes and experiments in this sense: Eco-towns, environmental sustainable transport model project or eco model cities to name only the most important ones, or several schemes more directly dedicated to the promotion of eco-friendly vehicles as will be described later.

Today, the development of smart grids is a new technical step which opens up interesting perspectives and gives more emphasis on electrical vehicles, not only in terms of mobility but also in terms of storage. In Japan, the move towards smart grids demonstration has started in the early 2000s as in many other countries, but it is more concerned by achieving a low carbon society through using renewables as main source of energy supply (Ai Ling et al. 2012) than some other countries like France which focused more on better regulating demand to avoid peaks. The emphasis given to renewable energies was reinforced by the 2011 Fukushima accident which increased the awareness of energy consumption. It gave a new impulse to the promotion of low carbon cities namely through smart communities or smart cities projects which boomed recently all over the country whether supported per se by government funding or not. 
Among the numerous schemes and promotion programmes implemented by the Japanese Government which are often overlapping and can be used simultaneously by the different actors involved in experimentation, the programme called 'Demonstration of next-generation energy and social system' (2010) which gave birth to smart communities, is probably the most comprehensive one in that it proposes to test all the elements that compose the urban life under real-life conditions. In other terms, it appears as a tentative to test not only new technologies, new infrastructure and new services but also the interactions and interfaces between all of them, as well as the households' mobility and energy consumption.

This is why this paper focuses centrally on smart communities. But as the whole policy framework also benefits to smart communities which often are cities selected under several programmes, it first gives a short overview over some other schemes (Section 2). Taking the example of Toyota city where firms' consortium leader is Toyota Motor Corporation (TMC), Section 3 will then describe the main experiments in smart communities before examining some preliminary results in terms of households' behaviour. To conclude, Section 4 will point out some consequences that current and expected future changes might have on the mobility ecosystem and on the carmaker's business model.

\section{The promotion of next generation vehicles}

Although promoting next generation vehicles was already on the agenda before, Hatoyama, candidate of Democratic Party of Japan (DPJ), created a surprise during the 2009 campaign when he promised to cut $\mathrm{CO}_{2}$ emissions by $25 \%$ from the 1990 level until 2020 (Iida and De Witt, 2009). It made necessary to define demanding targets in all sectors including transport. The new growth strategy (see Jones and Yoo, 2011) and the Ministry of Economy, Trade and Industry (METI) Industrial Structural Vision 2010 have pointed out five strategic fields for the future. Smart-grid and next-generation vehicles were key industries in this sector. The same year, Ministry of Land Infrastructure Transport and Tourism (MLIT) also established its growth strategy, focussing on green innovation to promote modal shift, new-generation vehicles, houses and buildings with higher energy efficiency, and urban planning for a low-carbon city (World Bank and Japan International Cooperation Agency, 2011).

\section{1 $\mathrm{CO}_{2}$ emissions and the transport sector: changing urban mobility}

In 2010, the transport sector remains Japan's second producer of $\mathrm{CO}_{2}$ emissions (21\% of the total), far behind industry (38\%), but just before the 'commercial and others' sector (19\%), as shown in Figure 1. Over a long period, it appears that the $\mathrm{CO}_{2}$ emissions from transport reached a maximum at the end of the ' 90 s and then slightly decreased. Observing the energy consumption due to the domestic demand in transport in the long-term, it clearly appears that the use of private cars exploded in the ' 90 s, followed by the road freight transport (Figure 2). Since 1992, private cars represent more than $50 \%$ of the energy consumed by the transport sector, and reach 55\% in 2010.

As in some other industrialised countries (Van Dender and Clever, 2013), the 2000s show a historical change in this pattern with a stabilisation of traffic. This is generally 
explained by the increase of oil prices relatively to the households' incomes, which means the use of car becomes more expensive in relative terms, and many individuals try to reduce their mobility by car, especially for long distance trips (shift to railways).

In Japan, car traffic (measured in passenger $/ \mathrm{km}$ ) started to decline in 2004, i.e., some years before the present economic crisis. In 2009, car traffic decreased to a level similar to 1995 , which shows a structural change in households' behaviour (Figure 3). Then, energy consumption due to private car traffic logically decreased in volume. But it should also be noted that during the 2000s, the energetic efficiency of cars was not improved, despite the car makers' efforts to reduce the consumption of motors.

Figure $1 \mathrm{CO}_{2}$ emissions by sectors in Japan

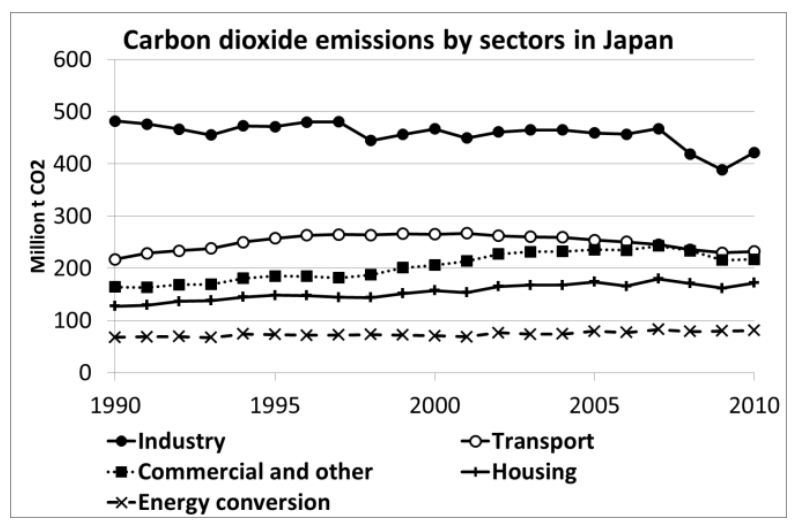

Source: Ministry of the Environment Government of Japan, Environmental Policy Bureau (2012a)

Figure 2 Energy consumption by transport modes in Japan

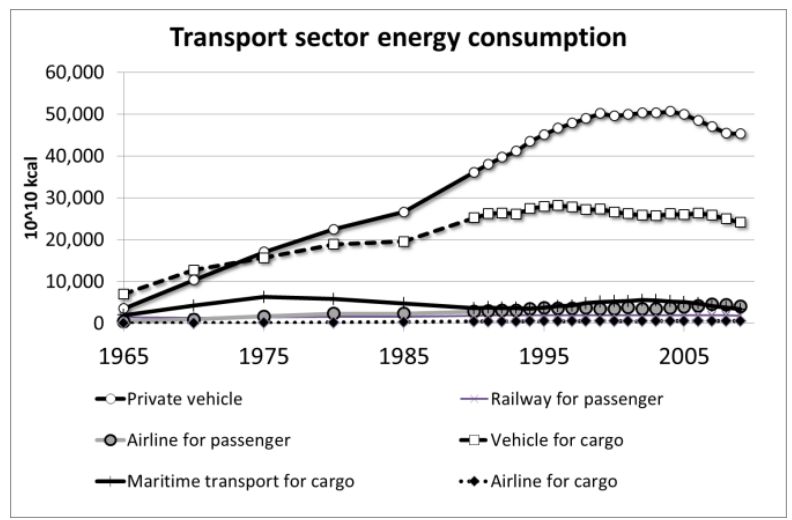

Source: Ministry of the Environment Government of Japan, Environmental Policy Bureau (2012b)

This phenomenon can be explained by different reasons. Some of them concern the evolution of the characteristics of new cars: the households' demand for more comfort and safety generally led to an increase of the weight of vehicles and the power of motors, 
two elements which do not favour a reduction of energy consumption. Another reason concerns the behaviour of households. They reduced long trips, by consequence, the use of cars became proportionally more important for short trips in dense areas, where traffic congestion reduces the speed and automatically degrades the energetic efficiency of private cars. In 2008 and 2009, it can be estimated that the economic crisis had a more comprehensive impact on households' mobility, including shorter trips.

Concerning passenger trips, the level of car ownership is similar to other developed countries, as shown in Figure 4. The rate of private cars owned by households (Figure 5) reached a maximum in the middle of the 2000s and shows a slight decrease in 2008, which can be seen as the consequence of the economic crisis, but also of the ageing of the population: the young appears to be less attracted by purchasing a car and prefers spending money in other expenditures (computers and multimedia devices).

Figure 3 Evolution of private car traffic and energy consumption in Japan

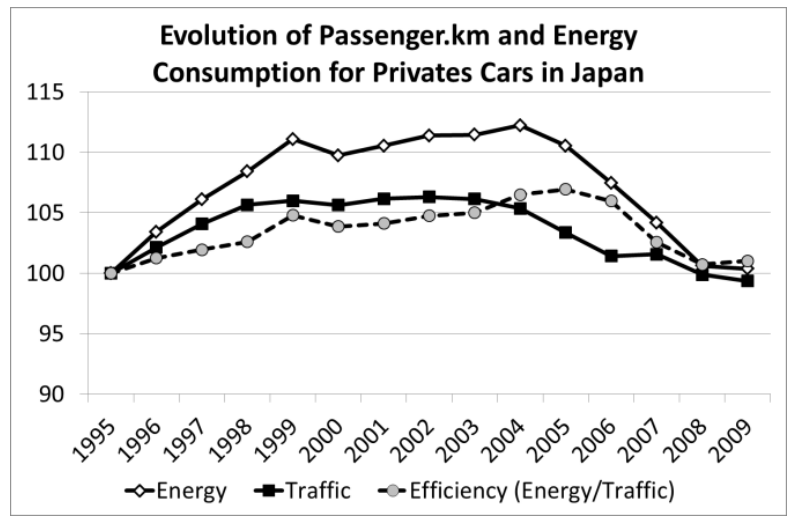

Source: Ministry of the Environment Government of Japan, Environmental Policy Bureau (2012b)

Figure 4 Car ownership in different countries

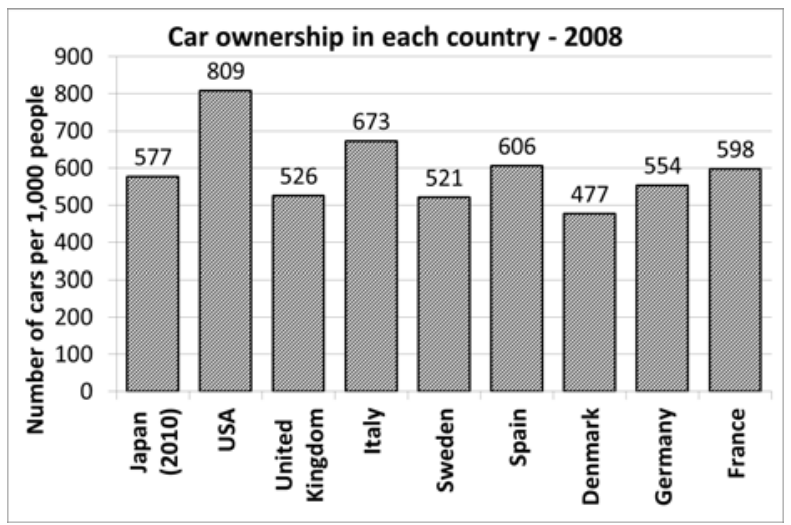

Source: Ministry of the Environment Government of Japan, Environmental Policy Bureau (2012c) 
Figure 5 Private car ownership in Japan

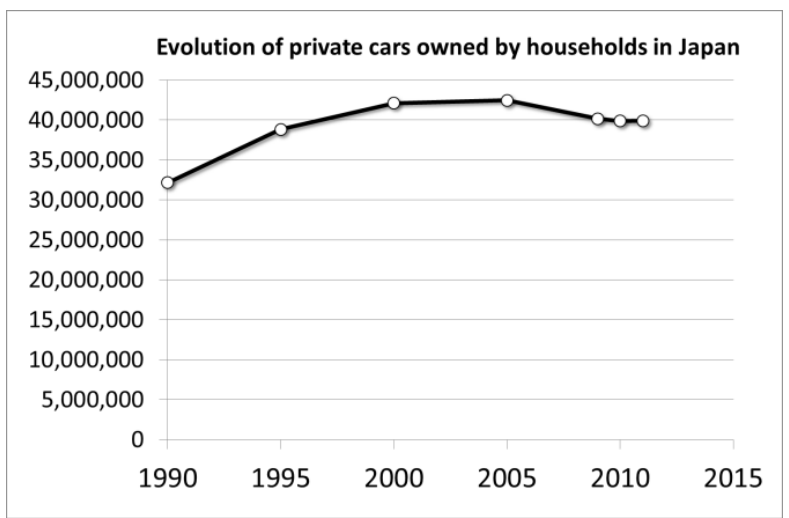

Source: Ministry of Land, Transport, Infrastructure and Tourism (2012)

Figure 6 Evolution of the modal split in Japan - Data: National person trip survey

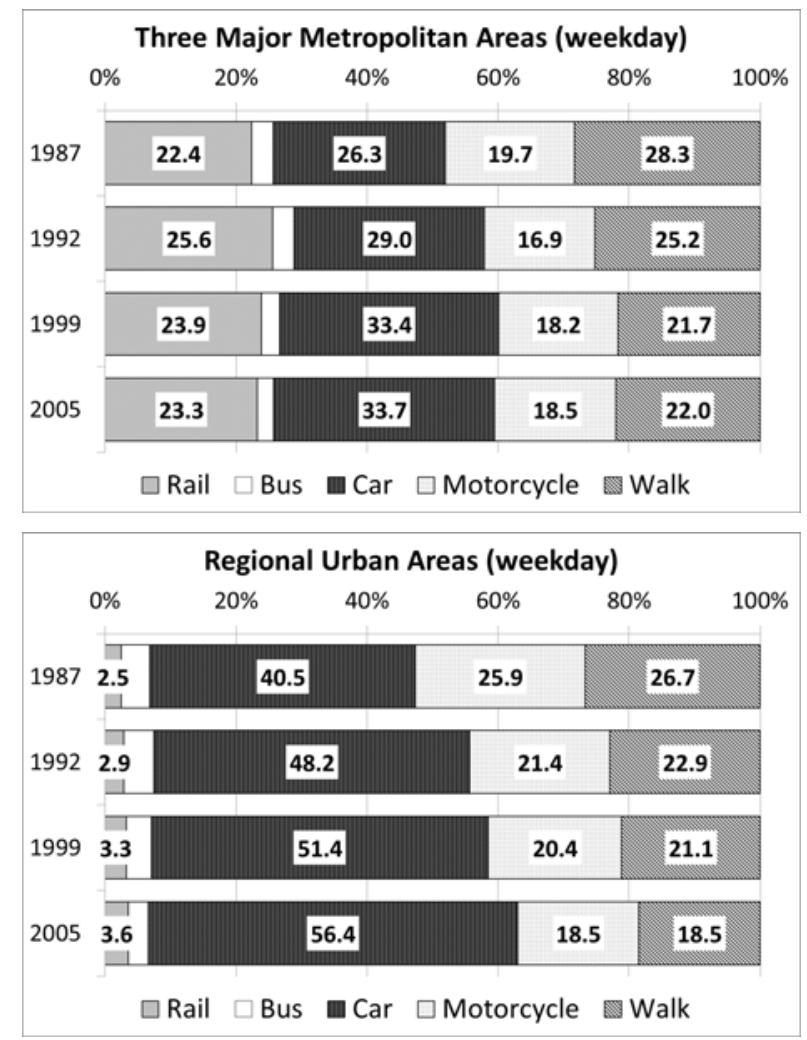

Source: Ministry of Land, Transport, Infrastructure and Tourism (2007) 
It is important to note that the mass transit system is well developed in Japan both for intercity trips and daily mobility, especially within the three largest metropolitan areas (Tokyo/Yokohama, Osaka/Kyoto/Kobe, and Nagoya), where the modal share is not in favour of private car use. Even if detailed results from the last National Trip Survey in Japan (2010) are not yet easily available, trends in the daily mobility for the past period shows the private car modal share was increasing, both in the three metropolitan areas and in other regional cities (Figure 6). The increase was, however, higher in regional urban areas. The importance of these three metropolitan areas in the total number of trips done by car is thus decreasing, from 18\% in 1995 to $15 \%$ in 2005 and $14 \%$ in 2008. This means, car use now concerns smaller cities, accounting for $86 \%$ of the traffic (Statistic Bureau, Ministry of Internal Affairs and Communication, 2012).

This rapid panorama of mobility in Japan shows that although car ownership tends to decrease, auto mobility remains important especially in regional urban areas. It explains why a lot is done to promote eco-friendly vehicles while optimising the urban transportation system as a whole.

\subsection{The promotion of next generation vehicles: preparing the future markets}

To prepare the market of next generation vehicles, METI launched a new programme in March 2009, 'EV/PHV towns', to pave the way for larger diffusion of EV and PHEV. ${ }^{1}$ The idea was to create through this programme an initial demand, to develop infrastructure and to organise events to educate the population. The initiative has started in summer 2009 for a 5 years period. Eight experimental prefectures were selected. In December 2010, ten other prefectures or cities were added to the programme bringing the number of experimental areas up to 18 . They are largely distributed over the country and involve metropolitan areas as well as smaller regional urban areas and even rather rural prefectures as can be seen in Figure 7. Under the programme, EVs were introduced as cities' or prefectures' public fleets, rental cars or taxi businesses and into some company fleets. Let us take the example of the Aichi prefecture were six cities participated in the initiative as well as the regional ${ }^{2}$ electric power company (Chubu electric power company), Toyota Motor Corporation and Mitsubishi Motors, but also 31 companies among which manufacturers and tertiary activities companies, including one car sharing, three car leasing, five parking, one airport and one railway company. The plan included the deployment of 1,000 to 2,000 EVs or PHEVs and the establishment of 141 charging facilities in the prefecture by 2013. In March 2011, 579 EVs or PHEVs had been introduced in Aichi prefecture through this programme (jisedai jidosha shinko senta (Next Generation Vehicle Promotion Center, 2012c).

In 2010, the Japanese Government fixed targets on the share that next generation vehicles would have to represent in the country's car fleet, to achieve the $\mathrm{CO}_{2}$ reduction goal and address the issue of progressively shifting to a low carbon society towards 2020 to 2030. As it can be seen in Table 1, these targets were quite demanding. In comparison, carmakers estimated that even with their efforts to develop alternative energy fuelled vehicles and promote them on the market, these would still account for less than $20 \%$ of the fleet in 2020.

In the same year, the Japanese Government outlined a new comprehensive plan for the development of next generation vehicles which is connected with the smart communities' experimentations also starting as we shall see later. 
Figure 7 EV/PHEV towns participating prefectures and cities

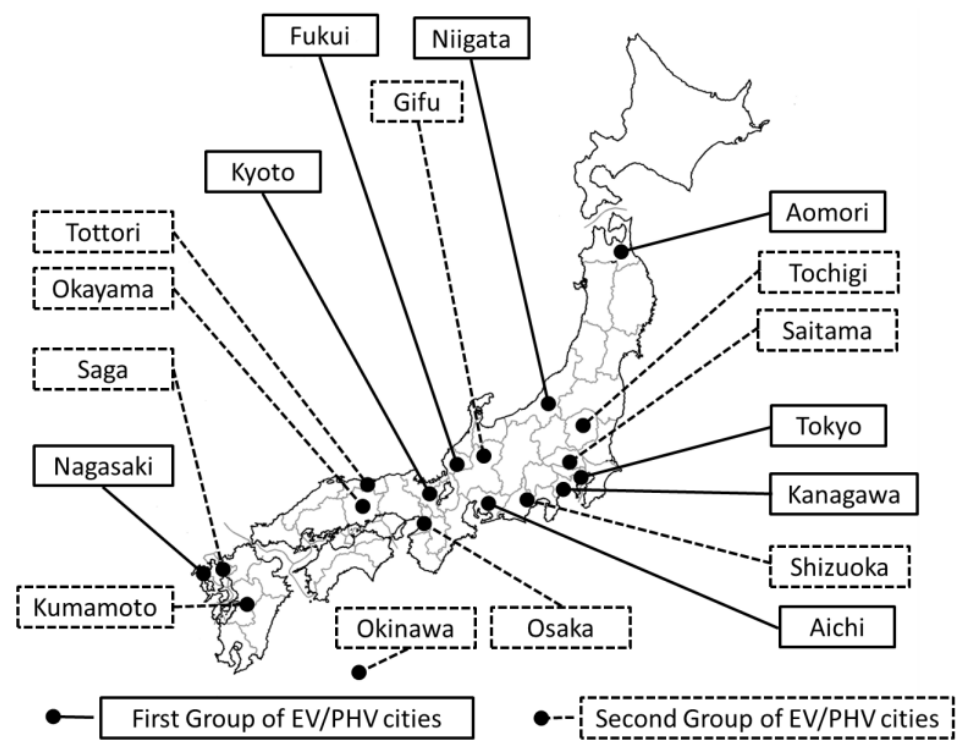

Source: Adapted from Tanaka (2010)

Table 1 Next generation vehicles market projections and government targets

\begin{tabular}{lccccc}
\hline & \multicolumn{2}{c}{ Projections (private sector estimate*) } & & \multicolumn{2}{c}{ Government targets** } \\
\cline { 2 - 3 } \cline { 5 - 6 } & 2020 & 2030 & & 2020 & 2030 \\
\hline Next generation vehicles & $<20 \%$ & $30 \%-40 \%$ & & $20 \%-50 \%$ & $50 \%-70 \%$ \\
Hybrid vehicles (HEV) & $10 \%-15 \%$ & $20 \%-30 \%$ & & $20 \%-30 \%$ & $30 \%-40 \%$ \\
$\begin{array}{l}\text { Electric/plug-in hybrid } \\
\text { vehicles (EV/PHEV) }\end{array}$ & $5 \%-10 \%$ & $10 \%-20 \%$ & & $15 \%-20 \%$ & $20 \%-30 \%$ \\
Fuel cell vehicles (FCV) & miniscule & $1 \%$ & & $0 \%-1 \%$ & $0 \%-3 \%$ \\
$\begin{array}{l}\text { Clean diesel vehicles } \\
\text { (CDV) }\end{array}$ & minuscule & $0 \%-5 \%$ & & $0 \%-5 \%$ & $5 \%-10 \%$ \\
\hline
\end{tabular}

Notes: Share of next generation vehicles of total new vehicles.

*2010 estimated, based on previous period with no existing incentives and on the hypothesis that the market would grow by $10 \%$ or some more.

**Targets set by government in 2010 as a basis for policy definition to implement measures for the promotion of next generation vehicles.

Source: Jisedai jidosha shinko senta (Next Generation Vehicle Promotion Center) (2012c, p.2)

\subsection{Incentives dedicated to next generation vehicles}

Automobile related taxes are high in Japan [Tanaka, (2012), p.17]. But under the Japanese tax system to promote the diffusion of environmentally friendly vehicles, eco-friendly vehicles such as EVs or PHEVs benefit as next generation automobiles from tax breaks. They are fully exempted from the automobile acquisition tax and the 
automobile weight (tonnage) tax, while under the automobile green tax scheme the automobile tax is reduced by $50 \%$.

Figure 8 Changes in the government support for purchasing alternative fuelled vehicles
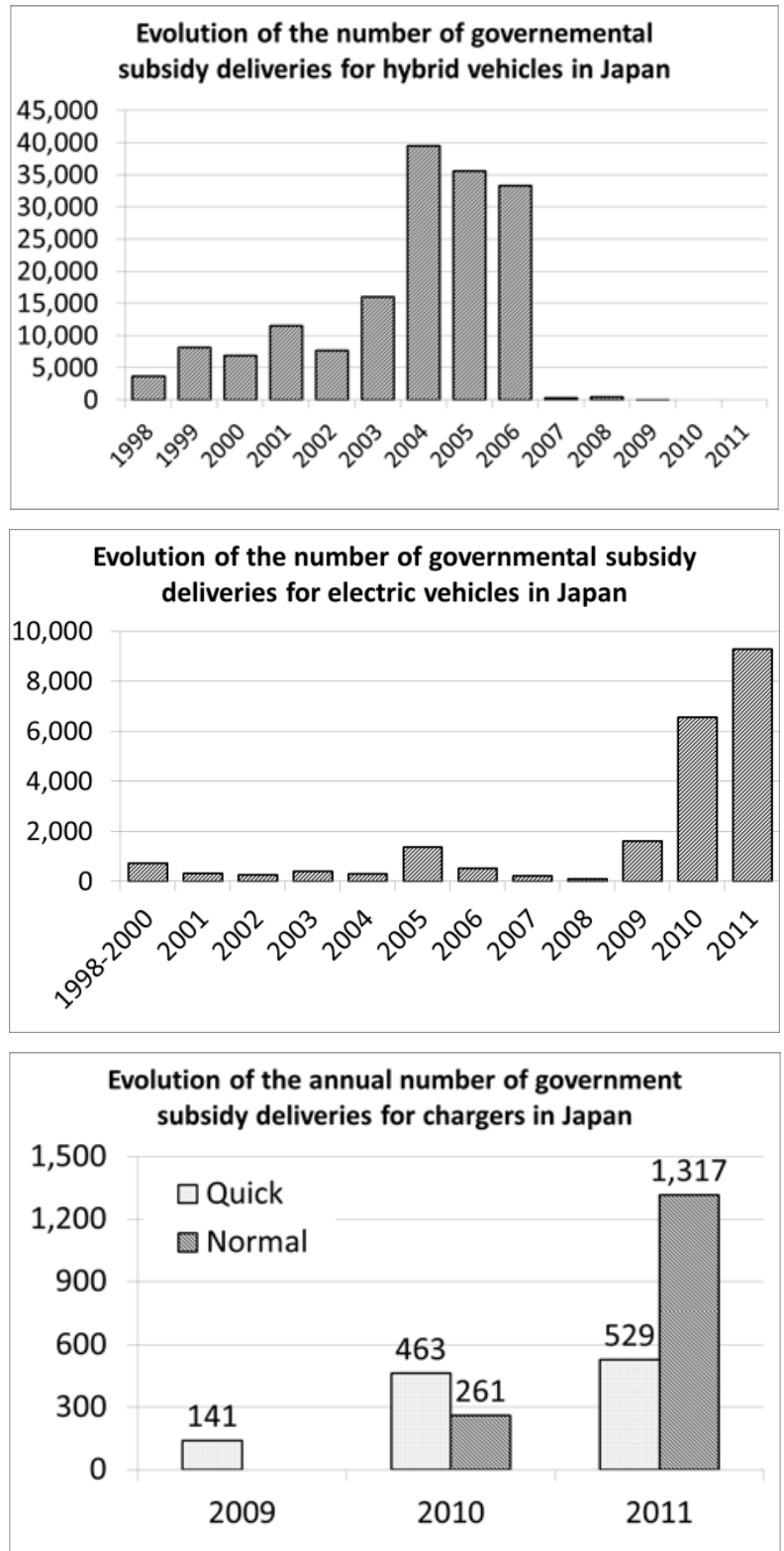

Source: Jisedai jidosha shinko senta (Next Generation Vehicle Promotion Center) (2012a) 
In addition, subsidies are given to local authorities, private companies and individuals/households until half of the difference between the price of a gasoline car and the price of an equivalent EV or PHEV, with a limit of 1 million yens (see Figure 8). A minimum of four years ownership is requested to subsidise the purchase. The subsidy amount for each year and each scheme is fixed at a certain level. The scheme might be closed before term if the maximum amount is reached earlier due to numerous applications.

More concretely, let us take the example of the Nissan Leaf launched in December 2010 in Japan. It has a $24 \mathrm{kWh}$ capacity lithium-ion battery with a maximum power output of more than $90 \mathrm{kWh}$, allowing with a full charge to drive $200 \mathrm{~km}$. The price starts from 3,764,250 yen (consumption tax included). Thanks to Japanese Government incentives, buyers can save until 780,000 yen (fiscal year 2010 incentives scheme), that is a saving of about 20\%. As Figure 8 shows, a shift occurred in 2007 in the government priorities, transferring subsidies from HEV to EV (later including PHEVs) purchases. The HEVs market growth (see Figure 9 hereinafter) might explain why, after 2006, subsidies appeared unnecessary. Demand for subsidies for EVs purchasing start in 2009 only and really took off since 2010; the crisis might be one reason, but new EV model launches might also explain such an increase.

As charging infrastructure is a precondition for the population to shift to next generation vehicles, charging facilities installation is also subsidised at around half of its cost (eventually complemented by regional or cities' initiatives; Tanaka, 2012). Like in the case of vehicles, a minimum of eight years ownership is requested if the purchase was subsidised. This next generation vehicle promotion scheme was first (2009) dedicated to quick chargers infrastructure, but in 2010, METI started focusing more on normal chargers mostly to promote charging devices in houses or housing buildings (see Figure 8).

All these elements show clearly the significant efforts from the Japanese Government for the uptake of electric vehicles. But these incentives cover only a part of the 'electric vehicle system', which needs a more comprehensive approach in relation with the objectives of reducing $\mathrm{CO}_{2}$. Such an approach taking into account energy consumption (transport and buildings) and households' behaviours will be the basis for a new policy.

\section{The smart communities experimentations: companies' involvement and population behaviour}

Since 2010, METI initiated an extensive programme, beyond the mere optimisation of energy management, to promote the development of 'smart communities'. Their aim is to encourage the population to participate in the regulation of energy demand, including their daily way of life. The generalisation of energy management systems (EMSs) enables to define multiple levels of regulation of energy demand for all components of a local community. So, we speak of home energy management systems (HEMS), factory energy management systems (FEMS), building energy management systems (BEMS), connected to a community energy management system (CEMS) managing smart grids and battery storage systems (including electric vehicles recharging).

An EMS aims at spreading the energy demand peak by storing off-peak energy production in batteries, in order to avoid costly or environmentally not friendly production of overcapacities. This way, renewable energy production (for example from 
photovoltaic 'positive energy' buildings) can be better valorised, and EVs offer a complementary advantage, as an additional storage capacity. Such an integration of energy distribution, buildings and means of transport constitutes the innovative aspect experimented in smart communities.

\subsection{Smart communities: more than a change of scale?}

Smart communities are defined as a "regional deployment of next-generation energy and social systems that combine in multiple ways concepts such as the 'coordinated use' of energy, which means effectively using not only electricity but also heat and untapped energy as well as the transformation of regional transport systems and people's lifestyle" (Ministry of Economy Trade and Industry, 2012). The aim of the smart communities goes therefore beyond the simple regulation of the energy flows, since it is also about involving people, services and companies in the creation of less energy-consuming lifestyles to promote the reduction of $\mathrm{CO}_{2}$ emissions.

The programme relies on a number of demonstrators chosen among the 20 cities that have submitted a project within the programme. METI has selected four sites according to the quality of the projects, but also to specificities of each geographical area. Indeed, each selected area allows testing different configurations in conjunction with its characteristics. A large metropolis in the case of the city of Yokohama, a provincial town in the case of Toyota city, a science park for the Kyoto-Keihanna district and a special area in an industrial city for Kitakyushu (Lecler, 2012).

This comprehensive programme, involving both public and private actors, is also part of a clear industrial strategy addressing the conversion of Japanese flagship industries and the definition of new international standards. ${ }^{3}$ In particular, it addresses the:

- Consumer electronics industry which is losing speed compared to Asian neighbours on its traditional segments (computers related products etc.), while new green technologies related segments such as information systems for energy or transportation uses are seen as the markets of the future.

- Car industry which is facing overcapacities at least in the triad economies while mobility behaviour of the population namely in urban areas is changing along with the gasoline price and a certain awareness of environmental issues, but also due to environmental regulations.

The transport system is part of all smart communities experiments. But the extent to which new solutions are tested and their nature depend on their location's specificities or on strategies of firms involved. In all cases, experiments involve many stakeholders but, depending on the carmaker integrated in (or leading) the firm consortium, technical solutions tested might differ, as we shall see later. Whichever the solutions tested in terms of mobility, these cannot be isolated from those in terms of housing, energy management, real-time information systems which communicate data and advice to the households or individuals regarding their activities, their energy consumption or their mobility patterns.

This is concretely illustrated by the case of the Toyota city smart community project, named Smart Melit (Smart Mobility and Energy Life in Toyota City) described below. It clearly shows that TMC, leading the firm consortium, is engaging in numerous industrial or service activities which are not related to car production or even not limited to auto-mobility. 


\subsection{The concrete experimentations: the example of smart mobility and energy life in Toyota city ${ }^{4}$}

Toyota city is a medium-sized city of 422830 inhabitants (April 2012) which covers a vast surface, including forestry $\left(918 \mathrm{~km}^{2}\right)$. It is located in the Aichi prefecture which it is the second city (after Nagoya) in terms of population but the larger one in terms of surface. In comparison to large Japanese conurbations like Tokyo/Yokohama or Osaka, auto-mobility is quite important in Toyota city and in its regional periphery (including Nagoya). But like other carmakers, TMC is well aware that this will change in the future.

To prepare for future developments, TMC engaged in the smart community project of Toyota city which costs roughly 6 billion yens (about 47 million $€$ ), half of it being funded by METI and the other half corresponding to the cost of research, development and tests done by consortium partners (it probably also benefits from actions developed under former programmes, such as the Eco-Model City). For example, TMC is funded for the development of the energy data management system (EDMS, name given to the CEMS in Toyota city) which is one of the central elements of the project, but the company is also developing without any financial support from METI, a lot of other technologies which could lead to new marketable products. TMC does not believe that 'smart community' will become a marketable product/service as a whole, but is confident that most of the elements under experimentation will be marketable separately, justifying the company investment and the entrance in the energy domain.

\subsubsection{The smart houses experimentation}

The experimentation takes place on some specific areas, including:

- two districts of Toyota city where 67 smart houses have been built: Takahashi (39 houses) and Higashiyama (28 houses)

- two commercial buildings, one distribution center, and Toyota Ecoful Town, constructed to showcase the city's efforts to build a low-carbon society

- 160 older pre-existing residences.

At the survey time (March 2013), 64 of the newly built smart houses had been sold and were already occupied (since one year for the oldest occupancy). Most of the people bought these houses, the price of which is high (48 million yens - about $375 \mathrm{k} €$ for a land surface of 120 to $160 \mathrm{~m}^{2}$ ), due to the nice location and the proximity of schools. Although concerned by energy or environmental issues, this was not the reason for choice. Each one of these houses is equipped with solar panels on the roof, external storage batteries and plug-in devices. They have a HEMS sending data to the EDMS which returns information about the district consumption and sends demand-response (DR) alerts when needed. All this is available on the EDMS portal where a lot of data are visible (energy consumption of the community, amount of electricity generated by the solar power generators, amount of emitted $\mathrm{CO}_{2}$ ). A special page calculates results for each household and compares these to other ones in the community to give each family its own ranking. Information is visible on the HEMS screen, on the computer but also on an electronic photo frame usually loaded with family photos. The frame becomes blue if consumption is reaching a peak and red if DR action is needed, indicating the elements of the dynamic pricing system. ${ }^{5}$ Information is updated every 30 minutes. 
In the older residences, smart metres with visualising functions are progressively installed by the Chubu electric power company. Tests were conducted in January and February 2013 with the concerned 160 households; the 80 households implementing DR having been compared with the other 80 who did not. At the survey time, results were not yet announced.

\subsubsection{Powering houses and cars by renewables: vehicle to home and home to vehicle $(\mathrm{V} 2 \mathrm{H})$}

The Toyota city project relies on renewable energies (61.2\% rate as a target) mainly from solar source as illustrated by the smart houses which are supposed to produce their own electricity. Although Japan has a feed-in tariff (FIT) system, priority is not to sell excess production to the Chubu electric power company but to store it in external batteries and so to limit as much as possible the need to buy electricity when production is not sufficient. EVs or PHEVs bought by Toyota city's citizens or companies on the market are participating in this process (around 300 PHEV in 2013, 4,000 are targeted at the end of the project). For the moment, users are demanded to charge their vehicles taking into account EDMS data, meaning that they are supposed to delay charging out of peak time or to use external batteries if needed. Such a 'right' behaviour is awarded by points in the Toyota city project eco-points system.

But TMC is also testing a two-way electric power supply system in 30 households. Although TMC has developed an electric car, the company priority is to promote its PHEVs on which V2H tests are performed. V2G (vehicle to grid) which also was on the government agenda, is not experimented in Toyota city. In the districts where smart houses were built, from the 64 households settled there, 60 have a PHEV, the four others having chosen an EV. According to these tests, a plug-in Prius battery, which can be charged in some 90 minutes, provides electricity for three days to a standard family (parents 1 child; $10 \mathrm{kwh}$ ). Power flow is controlled according to communication between the vehicle, the charging point and the home, also ensuring that recharging will begin out of peak time. This system allows to benefit from green electricity produced by the house (or later by regional solar generators) or from low cost night electricity, making car an additional storage capacity that can be used to power the house during peak times. The HEMS automatically control the energy flow. In case of emergency or disaster, the system can be manually monitored to use the PHEV to power the home during three to four days.

\subsubsection{Harmonious mobility or Ha:Mo}

In Toyota city, in addition to the HEMS/EDMS and V2H experimentation, TMC is also testing its ‘one mile mobility system' called 'HA:MO Ride'. Ha:Mo Ride is a one-way car-sharing system launched in October 2012. The vehicle used is the COMS manufactured by Toyota Auto Body. It is a one seat small chassis ultra-compact electric vehicle with lateral doors in plastic closed by zips. The capacity of the motor is $0.59 \mathrm{~kW}$ while the storage battery is $5.2 \mathrm{kWh}$. It can be fully charged within six hours, its travelling distance is approximately $50 \mathrm{~km}$ and its maximum speed is $60 \mathrm{~km} / \mathrm{hour}$.

In the initial testing phase, the service is offered free of charge and tested on students and employees of Chukyo University for trips between the train station and the campus with few members (ten progressively enlarged to some 100). Four stations covered with 
solar panels have been opened in front of the university and closest train stations. TMC and Toyota city intend to increase the number of stations to 10-20, with some 100 vehicles available within one year. At that moment 1,000 members are expected and fees will be charged.

Members use their smartphones to check if EVs are available at each station. The Ha:Mo Ride Support centre indicates the level of battery charge and so the number of possible $\mathrm{km}$ of each vehicle available. It also checks if a place is free at the final destination station and if distance to drive or availability of COMS returning parking is not ensured, the reservation is rejected.

After few months testing, results were less than expected level. TMC was targeting six rotations a day for each COMS but at the survey time (2013 March 5), the average was only 2.5 .

The system was extended in October 2013 (Japan Smart City Portal, 2013), with the number of station increased to 22 and the number of COMS to 100. Reservation can be made until 30 minutes before use. The expectation of membership is almost achieved with 950 members. Most are employees of TMC or related companies. This might confirm that for a broader use among population, the one-seat vehicles is not well adapted, making the service less suitable for example for housewives with a child to go shopping. As previously planned, the service which was free at the beginning is paid since December 2013: 200 yens the first 10 minutes, then 20 yens per minute with a special price when the vehicle is parked, 1 or 2 yens per minute depending on the period of the day. There is however no membership fee.

In addition, a motor-assisted bicycle-sharing service is also proposed with since October 2013, 62 bicycles available at 15 stations (30 minutes free, then 50 yens per 10 minutes).

Ha:Mo also includes a 'Multi Modal Navi route guidance system' ${ }^{6}$ which is an ITS service operated via a smartphone application. It was opened in October 2012 by TMC, Toyota city and transportation companies. The service aims at providing information on transportation alternatives (route guidance combining automobiles and public transportation) and so at encouraging the use of the optimal combination of transport modes based on traffic conditions etc. It will also provide support for parking availability when a personal car is used. The service includes all transportation modes available including Ha:Mo Ride for the last kilometre which is reserved automatically if the user confirms following the suggested route. In that case, if using collective transport or car sharing, the choice will be eligible for receiving points of the city eco-points system. The goal is of course to reduce traffic congestions but also $\mathrm{CO}_{2}$ emissions thanks to eco-driving and off peak automobile use.

To complete all this, seven charging stations have been installed in several parts of the city. Equipped with smart devices recognising the type of vehicle/battery, they can be used for both EVs and PHEVs. Stations offer fast charging facilities that are able to check the power available and to decide whether to charge the car fully or not. $5 \%$ to $10 \%$ of the charge is from solar sources while the major part is still conventional electricity. TMC and Toyota city are also considering charging vehicles at commercial facilities, especially as far as delivery vehicles are concerned. One convenience store chain, involved in the Smart Melit project, experiments this service with two companies: Yamato and Denso. The issue here is that charging will not necessarily occur from solar source and might constraint the commercial facility to upgrade its contract with the 
electricity power company, increasing the financial burden as charging is supposed to be free of charge.

\subsubsection{Ecoful town and fuel cell hybrid bus}

The Ecoful Town which is a demonstration area for public information opened in May 2012. It is located at a 10-15 minutes walking distance from the city centre. It includes a large building called 'Pavilion' where all eco-friendly technologies and applications can be seen through videos or testing devices. The pavilion roof is covered by solar panels powering around $40 \%$ of its consumption. At high production time, electricity is stored in seven external batteries which are connected to the building but also to a EVs/PHEVs charging station (three parking slots provided with solar energy). A smart house was under construction at survey time for citizens to visit.

The Ecoful Town area also includes a hydrogen charging station (not yet opened at survey time). The problem of hydrogen stations and therefore of fuel cells is linked to regulation that prohibits stations in dense urban areas. TMC is testing a fuel cell hybrid bus with a line serving the university campus. ${ }^{7}$ This bus is equipped with the new power supply system and has two electrical outlets (AC $100 \mathrm{~V}, 1.5 \mathrm{~kW}$ ) that can supply a maximum output of $3 \mathrm{~kW}$. TMC is jointly developing a V2H system for fuel cell buses which could provide power to the big infrastructure in the city in case of emergency for example. Estimation gives that a full tank of fuel cell bus could power a school gymnasium for some five days. TMC plans to start fuel cell buses V2H in late 2013/early $2014 .^{8}$

\subsection{Next generation vehicles market and households' e-mobility: some preliminary results}

As the case of Toyota city shows, several concepts are in fact experimented in the smart communities, corresponding to what could be considered new e-automotive services. Automakers might have to develop them further and/or coordinate with energy companies, battery and charging infrastructure manufacturers but also information systems developers if they want to keep a certain control on the whole value chain as it was the case in the past. These range from:

- $\quad$ promoting the creation of company or district-wide vehicle fleets on the model of car-sharing or self-service car, leading to a dissociation of car ownership and car use

- $\quad$ regulating travel demand, which now requires multimodal information (public transport but also walking), to promote a reduction in power consumption, and smoother traffic

- developing completely new technologies and concept such as V2H while integrating cars into the EMS; in other terms, while giving to next generation vehicles a new role as a storage device in addition to its former one in the mobility chain.

The results of all these experimentations which are in progress and still at the testing level are of course difficult to predict, but they certainly contribute with other schemes and incentives to the recent increase in EVs and PHEVs purchasing.

As shown in Figure 9, the purchase of electric cars is emerging in 2010 and plug-in hybrid cars in 2011. In cumulative numbers on the 2005 to 2011 period, even if the 
volume remains low compared with hybrid cars (close to 6 million), the EVs fleet increased by 35,000 units and the PHEVs fleet by nearly 5,000. This confirms the start of the market, which was pushed by the great number of promotion measures and subsidies by the government for purchasing electric vehicles.

Figure 9 Annual purchase of electric vehicles per category in Japan (2005-2011)
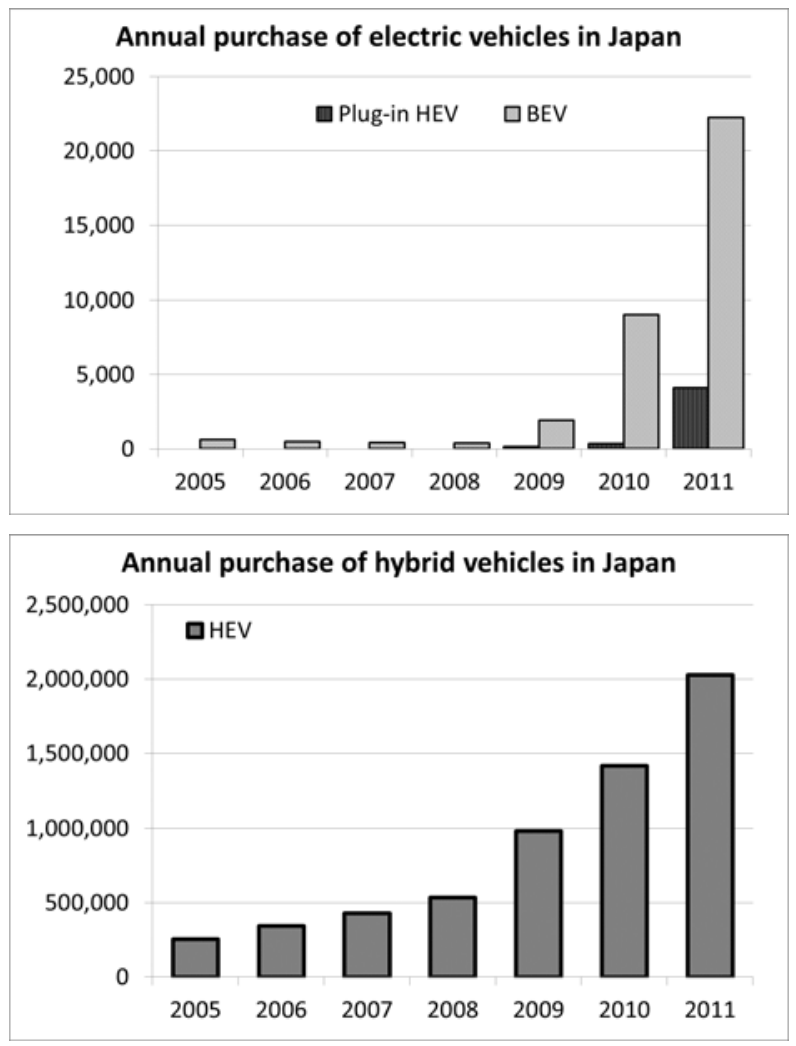

Source: Jisedai jidosha shinko senta (Next Generation Vehicle Promotion Center) (2012b)

But, the market is also increasing thanks to the development of charging infrastructure without which the efforts on car purchasing would have been wasted investments. Indeed, although most users charge their EVs at home, the EV/PHEV booms tend to boost a charging infrastructure industry. Shopping centres and convenience stores install chargers to attract customers, parking lots provide charging facilities, and even some private business owners have installed chargers for their visitors/customers [see Tanaka (2012) for more examples]. As we have seen in the Smart Melit experimentation of Toyota city, TMC cooperates with convenience stores to propose charging solutions. In the case of the Nissan Leaf already mentioned, 200-volt normal charging has been made available at about 2200 Nissan dealers nationwide. About 200 of these dealers are equipped with quick chargers that can charge the battery up to $80 \%$ of its full capacity in about 30 minutes. At the same time, electronics and information/telecommunication 
companies such as Toshiba, Hitachi, NEC are also involved in charging infrastructure and their management systems. The interrelation of this new industrial segment with the vehicle manufacturing industry or other sectors (energy, electronics and information/communication) is still unclear, but also has to be taken into account.

According to the Next Generation Vehicle Promotion Center's survey of March 2012, public or private normal charging facilities installed in Japan were 4,320, while quick chargers were at 848. These numbers are still far from the 2 million and 5,000, respectively projected for 2020, but show that along with the development of a EVs/PHEVs market, thanks to incentives but also to private companies' investments, a charging infrastructure industry is progressively taking shape. Japanese companies involved in charging infrastructure business through smart cities experimentations or any other projects do not want to miss the opportunity of the future global market which, as Navigant Research (2013a) estimates, would grow of 27\% annually from $\$ 713$ million in 2013 to $\$ 3.8$ billion by 2020. The report shows that at the end of 2012 there are 48,705 publicly accessible charging stations installed globally, the greatest number being in Asia-Pacific region leading far in front of the US followed closely by Europe.

According to a web survey done in January/February 2012 for the Next Generation Vehicles Promotion Center on the evolution of electro mobility in Japan, it is possible to obtain some information about attitudes towards e-mobility (although the sample is still limited in terms of number of individuals or households and companies concerned). It is divided into two categories, households (31) or companies (47) owning an $\mathrm{EV}^{9}$ and households (206) or companies (52) intending to buy an EV or a PHEV and having already made some steps in that direction (at least visited a showroom). As it can be seen from Table 2, households owning an EV or a PHEV are for their great majority travelling less than $30 \mathrm{~km}$ per day as annual average, the EV being the main car (55\%) or the second car (45\%). Most are living in individual houses (90\%) indicating clearly that charging infrastructure in collective mansion building matters.

Table 2 Annual travelled distance

\begin{tabular}{lccccc}
\hline Annual travelled distance & Sample & $<5,000 \mathrm{~km}$ & $5-10,000 \mathrm{~km}$ & $10-15,000 \mathrm{~km}$ & $>15,000 \mathrm{~km}$ \\
\hline $\begin{array}{l}\text { Households owning EVs } \\
\text { Companies/commerce }\end{array}$ & 31 & $12(39 \%)$ & $12(39 \%)$ & $6(19 \%)$ & $1(3 \%)$ \\
$\begin{array}{l}\text { owning EVs } \\
\begin{array}{l}\text { Households intending to } \\
\text { buy EVs/PHEVs }\end{array}\end{array}$ & 206 & $59(29 \%)$ & $88(43 \%)$ & $38(18 \%)$ & $21(10 \%)$ \\
$\begin{array}{l}\text { Companies/commerce } \\
\text { intending to use }\end{array}$ & 52 & $8(15 \%)$ & $20(39 \%)$ & $18(35 \%)$ & $6(12 \%)$ \\
\begin{tabular}{l} 
EVs/PHEVs \\
\hline
\end{tabular} & & & & & $1(2 \%)$ \\
\hline
\end{tabular}

Source: Jisedai jidosha shinko senta (Next Generation Vehicle Promotion Center) (2012c, p.36)

Table 3 shows that the way they use their car is not different from the use of conventional cars: it is shared between home-to-work, shopping and leisure trips. However, considering that only one among two persons declares using it for home-to-work trips, it is less than the usual pattern (except in the case of Tokyo/Osaka areas). One reason might be that EVs/PHEVs owners are mostly using their car for proximity trips, assuming that the distance it can run is not enough for usually longer home-to-work trips. Another reason might be that they are mostly living in areas where the collective transport system 
is efficient enough for them to avoid using their car. On the companies' side, 58 of those owning an EV are also in majority travelling less than $30 \mathrm{~km}$ a day mostly for professional trips or deliveries, the second largest share of trips. The EV is not used as much as in the case of households with $6 \%$ using it every day and $19 \%$ three to four times a week.

According to the same survey among households or companies who intend to buy an EV or a PHEV, $24 \%$ of households (of which $78.0 \%$ would consider it as a main car), and $19 \%$ of companies declare being in favour of an EV. 38\% of households (of which $78.5 \%$ would consider it as main car), and $55 \%$ of companies are in favour of PHEV. The remainder of surveyed households or companies did not choose yet.

Only $10 \%$ of households owning an EV did not know about V2H. Among those knowing about it, $13 \%$ are already using it while 61\% would like to try. Surprisingly, companies seem less interested in $\mathrm{V} 2 \mathrm{H}$ as $19 \%$ did not know about it and among those who knew, only $6 \%$ are already experimenting and 55\% would like to do.

A more in depth survey on a larger sample would be necessary to verify these results.

Table 3 Trip purposes of EV and PHEV owners in absolute numbers (and \% share)

\begin{tabular}{lccc}
\hline & Trip purposes & $\begin{array}{c}\text { Households } \\
\text { owning EVs (31) }\end{array}$ & $\begin{array}{c}\text { Companies and commerce } \\
\text { using EVs (47) }\end{array}$ \\
\hline Private use & $\begin{array}{c}\text { Home to work/school trips } \\
\text { Shopping, accompanying, } \\
\text { personal activities }\end{array}$ & $14(45 \%)$ & $4(9 \%)$ \\
& Leisure (cruising, sports, & $29(94 \%)$ & $2(4 \%)$ \\
Professional & Oeisure) & $16(52 \%)$ & $11(23 \%)$ \\
use & Dethers & $4(13 \%)$ & $39(83 \%)$ \\
& Professional trips & $3(10 \%)$ & $4(9 \%)$ \\
Taxi & $2(7 \%)$ & $2(4 \%)$ \\
& Commercial trips & $1(3 \%)$ & $1(2 \%)$ \\
\hline
\end{tabular}

Source: Jisedai jidosha shinko senta (Next Generation Vehicle Promotion Center) (2012c, p.36)

\section{Concluding remarks: resulting issues for the car industry}

To cope with the objective of a low-carbon society, the Japanese Government is encouraging a great number of experiments. Among them, the Smart Community concept seems to design a new and original integration between energy management, housing and mobility. A reduction in $\mathrm{CO}_{2}$ emissions indeed means to favour renewable energy sources for buildings and a complex EMS which needs a storage capacity offered by home and vehicles batteries. But it also involves some behavioural changes for households, especially in the way they manage their daily life and mobility.

In this sense, cities will encourage initiatives to moderate car use, not only for hometo-work trips, but also for all the short distance trips within the city. Then the management of information through IT systems, as well as financial incentives for a 
virtuous behaviour, will call for integrated solutions, through a mobility service package, letting people choose their mode of transport in a more rational way. The availability of transport alternatives is a necessary condition to facilitate such a behavioural change, but collective transport systems alone will not be able to cover the wide diversity of travel demand at satisfactory economic conditions. Thus individual transport systems will still be requested, but for a use which, depending on the type of trips, will be shared with other transport modes, or covered by private alternatively fuelled vehicles. In Japan, the price and tax incentives, added to the post-Fukushima awareness on energy, are paving the way to market growth of such vehicles. Even if the effort requested for energy saving leads to a greater multimodality, i.e. the capacity for individuals to choose the best mode of transport to optimise their energy consumption, an e-mobility market, although still small, seems now taking off. The number of next generation vehicles launched (EVs or PHEVs) is increasing while the brand choice is progressively enlarging worldwide. Navigant Research (2013b) estimates that for example, the number of plug-in electric vehicles on roadways will grow rapidly to more than 3,000,000 globally by 2017 .

In this context, strategies might differ between car makers, as the example of TMC and Nissan shows. Nissan focuses on EVs while TMC intends to develop its hybrid advantage further and believes more in PHEVs. Of course, TMC does not neglect EVs as illustrated by the small chassis models prototypes designed recently (such as i-ROAD for example) and which serve as basis for their concept of 'one mile distance vehicles'. TMC considers that in the future, short distance will be covered by electro-mobility with these small chassis vehicles; medium distance by Plug-in Hybrid Vehicles like the new Prius launched in Japan; and long distance by fuel cell technology with fuel cell passenger cars that several makers (Toyota, Honda and Nissan) announced for $2015^{10}$ (commercial launch in Japan).

Although carmakers agree with scholars on such a vision (Vitali, 2012), the new mobility ecosystem is not yet fully designed. As the case of Japan shows, many experiments are still ongoing. New technologies and e-automotive related services are tested in Japan and worldwide making it still difficult to know which one will offer best advantages. May be not yet foreseen mixed solutions will also emerge from research and experimentation, leading to not yet expected changes. Whatever the scenario will look like, the smart communities experiment already suggests that car makers will have to diversify their competences to cope with the new needs, They will have to offer both, a mobility service package including a variety of services, from individual transport systems (private car or car-sharing, but also two to three wheeled vehicles), access to a car-rental system, to multimodal information and to the public transport system, and a storage function (V2H, V2G). But they will then be in competition with other industrial players.

Batteries become the most important and expensive component in EVs. Japan has leading battery companies which make technological efforts to increase battery power while reducing their cost. But as for example the success of the Better Place Tokyo trial done in 2010 with a small number of taxis shows, swapping battery instead of recharging it might gain in interest in the future. ${ }^{11}$ We can see from this example that some companies could develop EV models without battery, but accompanied with a contractual battery switching service subscription. ${ }^{12}$ This service could be provided by an OEM under an agreement with battery makers or directly by the latter competing on that segment with carmakers or even by new companies proposing battery rental services. 
Some questions also remain concerning the future of the industrial and service segment of EV recharging. Stations are for the moment free of charge for customers in Japan. It is considered as a service to EV drivers, but even if future electricity provided might mainly come from solar source (it is not the case yet), investments alone are costly. As long as charging station will be subsidised and their deployment will be supported by public funding, companies might continue investing, but this situation will not last indefinitely. According to Charger Manufacturers Association (CHAdeMO), in order to build a real chargers manufacturing and managing industry with a large number of stations being created in the coming years, subsidies at the purchasing stage might not be enough. If charging cost remains on the provider side, it could limit installation. To avoid such an obstacle and permit a real new business to develop, charging fees paid by customers are necessary. Therefore, CHAdeMO member companies recently started to elaborate management and payment systems. Let us take the example of Hitachi. ${ }^{13}$ The company developed its own charging management solution, a system that processes information and monitors user authentication, fees, and payments for chargers. The Advanced Energy Company (AEC) has adopted this Hitachi solution as part of the Okinawa Green New Deal Project started in 2011. This plan based on the concept of a smart grid for remote islands aims among others at installing on Okinawa's main island 50 rental EVs charging stations with a rapid and medium-speed charger infrastructure by 2014. Presently, the service operates 220 EV rental cars and a total of 27 charging units installed at convenience stores, service areas, and other road-side sites. The EV rental car service is primarily aimed at tourists, who make frequent use of rental cars. Due to that the price of charging was fixed at 500 yens a charge, but in other region the price would be 100 yens.

The automobile value chain is already changing and will probably evolve further along with new technologies and services development. It brings new entrance opportunities for firms of other industries (energy, battery, car-rental/sharing companies...), which could take a certain control on the future mobility ecosystem. A lot of cooperation agreements have already been implemented between OEMs and ITC firms or battery manufacturers, high tech start-ups etc. (Vitali, 2012). Being able to develop and manage new e-mobility services might create a significant advantage over competitors in the future. But as the case of smart communities shows, integrating or controlling the e-mobility ecosystem might not suffice, as new services which are more linked to energy than mobility are devoted to vehicles such as the V2H or V2G. Therefore, the issue for carmakers is not only to develop and propose new models in the form of EVs, PHEVs or even FCVs. They also have to adapt to the larger paradigm shift that all these experimentations and promotion programmes are accelerating. This is probably why Japanese carmakers to start with TMC and Nissan but also Mitsubishi and Honda are so strongly involved in smart communities' demonstrators. These experimentations, compared to other numerous supporting programmes launched by the Japanese Governments in recent years, have the merit to allow testing, on a large and real scale, all elements of future cities/urban areas in an interconnected manner. Companies involved get the opportunity to enter technologies out of their past core competency areas as it is the case with TMC entering the energy management domain through the designing and development of the Toyota city EDMS, or new services such as Ha:Mo. The new business model that will emerge appears still difficult to predict and might differ depending on carmakers' own strategy to address the challenge. In order to keep a certain control on the whole value chain, they will have to integrate different industrial and 
services segments which were out of their scope in the past. They will have to build new inter-firms cooperation agreements with actors different from previous cooperation partners: raw material (used in batteries), services such as ITC services (not only for driving assistance but also for energy management), batteries or charging infrastructures manufacturers but also energy providers as the EV market evolution cannot be dissociated from the grid performance (Bompart et al., 2012). In that sense, making numerous stakeholders working together can also be seen as part of the learning process for the definition of the suitable business model of the future. Indeed, as the case of Toyota city has shown, each one of the demonstrators can be seen as a micro-local ecosystem (Charue-Duboc and Midler, 2012) where technical solutions, but also new industrial configurations and cooperation or even behaviour in a variety of contexts can be studied with the aim to measure suitable options for a broader deployment.

\section{Acknowledgements}

The research was funded by a grant provided by Région Rhône-Alpes.

\section{References}

Ai Ling, A-P., Sugihara, K. and Mukaidono, M. (2012) 'The Japanese smart-grid, initiatives, investments and collaborations', in International Journal of Advanced Computer Science and Applications, Vol. 3, No. 7, pp.44-54.

Bompart, E., Ragazzi, E. and Tenconi, A. (2012) 'Electric vehicles and power grids, challenges and opportunities', in Calebrese, G. (Ed.): The Greening of the Automotive Industry, pp.207-224, Palgrave Macmillan.

Charue-Duboc, F. and Midler, C. (2012) 'Balancing a strong strategic intent and an experimental approach to electric vehicles', in Calebrese, G. (Ed.): The Greening of the Automotive Industry, pp.89-102, Palgrave Macmillan.

Iida, T. and De Wit, A. (2009) 'Is Hatoyama reckless or realistic? Making the case for $25 \%$ cut in Japanese greenhouse gases', The Asia-Pacific Journal, 21 September, Vol. 38-4-09 [online] http://www.japanfocus.org/-Iida-Tetsunari/3226 (accessed 17 March 2012).

Japan Smart City Portal (2013) Improvements and Actual Cutover to the Ha:Mo Urban Transportation System, 18 December [online] http://jscp.nepc.or.jp/article/jscpen/ 20131218/377527/ (accessed 14 February 2014).

Jisedai jidosha shinko senta (Next Generation Vehicle Promotion Center) (2012a) [online] http://www.cev-pc.or.jp/tokei/koufu3.html, //koufu2.html, //koufu1.html (accessed 26 April 2013).

Jisedai jidosha shinko senta (Next Generation Vehicle Promotion Center) (2012b) [online] http://www.cev-pc.or.jp/tokei/hanbai1.html (accessed 26 April 2013).

Jisedai jidosha shinko senta (Next Generation Vehicle Promotion Center) (2012c) heisei 23 nendo denki jidosha nado no fukyu ni kansuru chosa (2011 Fiscal Year Survey on the Diffusion of Electric Vehicles), March [online] http://www.cev-pc.or.jp/chosa/pdf/2011_1_honpen.pdf (accessed 26 April 2013).

Jones, R.S. and Yoo, B. (2011) Japan's New Growth Strategy to Create Demands and Jobs, OECD Economics Department Working Papers, No. 890, OECD Publishing [online] http://dx.doi.org/10.1787/5kg58z5z007b-en (accessed 18 March 2012).

Lecler, Y. (2012) 'Smart communities in Japan: testing next generation energy', Paper prepared for the 9th EastAsiaNet Research Workshop, Aveiro, Portugal, 19-21 April. 
Ministry of Economy Trade and Industry (2012) Announcement of Master Plans for the Demonstration of Next-Generation Energy and Social Systems [online] http://www.meti.go.jp/ english/press/data/20100811_01.html (accessed 18 March 2012).

Ministry of Land, Transport, Infrastructure and Tourism (2007) 4th Nationwide Person Trip Survey, May [online] http://www.mlit.go.jp/crd/tosiko/zpt/pdf/zenkokupt_gaiyouban_ english.pdf (accessed 22 April 2013).

Ministry of Land, Transport, Infrastructure and Tourism (2012) Road Transport Bureau, (kokudokotsusho, jidoshakyoku) [online] http://www.stat.go.jp/data/nenkan/zuhyou/ y1205000.xls (accessed 22 April 2013).

Ministry of the Environment Government of Japan, Environmental Policy Bureau (2012a) [online] http://www.env.go.jp/en/statistics/data/e11ex202.xls (accessed 2 May 2013).

Ministry of the Environment Government of Japan, Environmental Policy Bureau (2012b) [online] http://www.env.go.jp/en/statistics/data/e11ex125.xls (accessed 2 May 2013).

Ministry of the Environment Government of Japan, Environmental Policy Bureau (2012c) [online] http://www.env.go.jp/en/statistics/data/e11ex149.xls (accessed 2 May 2013).

Navigant Research (2013a) Supply Equipment Tracker 1Q13: Electric Vehicle Supply Equipment Infrastructure Installations by Technology and World Region, Navigant Research Report Executive Summary [online] http://www.navigantresearch.com/wp-assets/uploads/2013/03/ TR-EVSE-1Q13-Executive-Summary.pdf (accessed 25 September 2013).

Navigant Research (2013b) Solar and Electric Vehicle Cross-Marketing Strategies [online] http://www.navigantresearch.com/research/solar-and-electric-vehicle-cross-marketingstrategies (accessed 2 April 2013).

Statistic Bureau, Ministry of Internal Affairs and Communication (2012) Japan Statistical Yearbook, Chapter 12 Transport and Tourism, Trend of Transport Volume [online] http://www.stat.go.jp/data/nenkan/zuhyou/y1203000.xls (accessed 24 April 2013).

Tanaka, I. (2012) Re-charged for Success: The Third Wave of Electric Vehicle Promotion in Japan, report of the Swedish Agency for Growth Policy Analysis, February [online] http://e-mobilitynsr.eu/fileadmin/user_upload/downloads/info-pool/Electric_Vehicle_Promotion_in_Japan.pdf (accessed 18 March 2013).

Tanaka, S. (2010) EV/PHV Towns for a Low Carbon Society, communication at 'Greening the City: Sharing Sustainable Urban Planning and Green-Building of LA and Eco-Cities in Japan_', seminar Co-organized by the City of Los Angeles, USGBC-LA and JETRO Los Angeles, Kyoto, 15 March [online] http://www.jetro.org/documents/green_innov/ Stephen_Tanaka_Presentation.pdf (accessed 26 April 2013).

Van Dender, K. and Clever, M. (2013) Recent Trends in Car Usage in Advanced Economies Slower Growth Ahead?, Discussion Paper 2013-09, International Transport Forum, Paris, France [online] http://www.internationaltransportforum.org/jtrc/DiscussionPapers/ DP201309.pdf (accessed on 18 December 2013).

Vitali, G. (2012) 'Agreements and joint-venture in the electrical vehicles industry', in Calebrese, G. (Ed.): The Greening of the Automotive Industry, pp.225-239, Palgrave Macmillan.

World Bank and Japan International Cooperation Agency (2011) Study of Japanese Experiences on Sustainable Urban Development including Pollution Control and Management, Resource/Energy Efficiency and GHG Reduction, Final Report, February, AMMEC Corporation [online] http://siteresources.worldbank.org/INTURBANDEVELOPMENT/ Resources/336387-1270074782769/6925944-1288991290394/Japanese_Experiences_ Sustainable_Urban_Development.pdf (accessed 3 January 2013). 


\section{Notes}

1 PHEV (or PHVs), containing both an internal combustion engine and an electric motor, share with all-electric vehicles a plug to connect to the electrical grid. Unlike former generations of hybrids (HEVs), the PHEV's electric motor is the primary source of energy.

2 In Japan, there are ten territorial energy monopolies which cover one region each. They control generation, transmission and distribution of energy. This system, which made electricity transfer from one region to another impossible after the Fukushima accident, will progressively come to an end up to 2020 (law of November 2013).

3 Since 2011, it is also seen as a solution for the future in the necessary reconstruction of areas devastated by the March 11 tsunami. Under the Future Cities Initiative launched in December 2011 for 5 years, Japanese authorities have selected eight 'smart city' projects as candidates to receive subsidies (up to 8 billion yens) among 50 initiatives from the Fukushima, Miyagi and Iwate prefectures.

4 This part of the paper is based on interviews at TMC headquarter and at Toyota city in March 2013, updated by public information mainly from the Japan Smart City Portal (http://jscp.nepc.or.jp/en/).

5 Electricity from Chubu electric power company is at some 21 yen/kwh. In the HEMS demonstration districts, it can fluctuate between 0 to 40 yens. An eco-point system with positive but also negative points when actions are contrary to required ones according to DR aims at incenting families to modify their way of using electricity and/or time of charging PHEVs/EVs.

6 First called HA:MO Navi, the service was renamed recently to avoid considering it just as a navigation system.

7 Two other FCHV lines already exist: from city to Central Airport (Nagoya) and from metropolis to Tokyo International Airport.

8 Some other elements are tested in the Ecoful Town such as on-demand buses or variable street use or access thanks to withdrawing slots and LED lighting.

9 The case of PHEVs is not taken into account for households or companies owning the vehicle because the number sold until survey time was very few.

10 In January 2011, Toyota, Honda and Nissan have announced jointly with ten energy companies that 2015 is the target year for an early commercialisation of FCV in Japan. Hydrogen fuel suppliers should build 100 charging station in the country until that year (Tanaka, 2012).

11 See for example, http://green.autoblog.com/2010/08/27/better-place-expands-tokyo-batteryswap-trials-taxis-have-chang/.

12 Renault experimented such a business model with its EV model Zoe (Charue-Duboc and Midler, 2012).

13 See Hitachi home page, mainly: http://www.hitachi.com/csr/highlight/2011/act1103/index.html\#act110301 and http://www.hitachi.com/products/smartcity/case/okinawa/index.html. 